freshly painted twice in the 1940's.

In the late 1930's my older brother observed a Sharp-tailed Grouse (Pedioccetes phasianellus) fly headfirst against an oat-bundle stack in midwinter (with no obvious injury to itself). The bundles were snow-free so that the stack made a sharp contrast with its lighter surroundings. This bird had flown as any grouse typically flies-in a straight line once it had taken off. A grouse may veer in its course, but its stiff-wins ed flight allows for little manoeuvrability. Witness the clicking sounds made by a Ruffed Grouse's wings as they hit against twigs or small branches in the bird's flight through woods. Since the Ruffed Grouse tends to fly close to the ground in its natural treed habitat, it is more likely than other grouse to meet obstacles in its path.

Through the years naturalists and woodsmen have added to our understanding of the Ruffed Grouse's crazy flight but more details of the circum- stances surrounding this curious phenomenon need to be recorded in the future.

\section{LITERATURE CITED}

Allen, A. A. 1928. The Ruffed Grouse investigation: progress report for 1928. Trans. 15th Natl. Game Conf. (Washington, D.C.), 8:3-8.8.

Audiubon, J. J. 1838. (Dover ed., 1967). The iirds of America, Vol. 5. New York.

Bent, A. C. 1932. Life histories of Nortl Anerican gra!linaceous birds. U.S. Natl. Mus. Bull. 162, Washington, D.C.

Bump, G., R. W. Darrow, F. C. Edminster, and W. F. Crissey. 1947. The Ruffer: Grouse: life history, propagation, mallagenent. New Y.sk State C ms. Dept., Albany.

Edminster, F. C. 1947. The Ruffed Grullis, its life story, ecology and management. Macmilin, N $\mathrm{N}, \mathrm{v}$ Yurk.

Forbush, E. H. 1927. Birds of Massachusetts and other New England states, Vol. 2. Berwick and Smith, Norwood, Mass.

Grange, W. B. 1948. Wisconsin grouse problems. Wisconsin Cons. Dept., Madison.

Gross, A. A. 1925. Diseases of the Ruffed Grouse. Science, $62: 55-57$.

Hall, H. M. 1946. The Ruffed Grouse. Oxford Univ. Press, New York.

Knight, J. A. 1947. Ruffed Grouse. Alfred A. Knopf, New York.

\title{
ANNUAL MAY-DAY BIRD COUNTS, 1971
}

Reports of the May-Day counts will appear in future in the Society's Newsletter, following a decision taken at a meeting of the Board of Directors earlier this year. However, since the counts have appeared regularly in the Blue Jay for a number of years, sumniaries of the 1971 reports submitted by Saskatoon and Regina are presented in this issue. Interested readers are referred to the full accounts which will appear in Newsletter No. 28, Summer 1971.

\section{Annual May-Day Bird Count, Saskatoon, May 14, 1971}

Fifty-nine observers in 11 groups drove 1,243 miles and walked another 30 this year to uncover $37,012+$ birds of 137 species. The species total (far below last year's record 162) is impressive when weather conditions and the scarcity of migrant flycatchers, thrushes, vireos, warblers and sparrows are taken into account.
Another factor was that this year's count was 8 days earlier than in 1970 . The day was cool with brisk NW winds which made it difficult to hear bird calls after 7 a.m.

The April-May migration this year was one of the most erratic in memory. The first migrants arrived earlier than usual. About 10 days prior to the count, migratory movements virtually ceased. Not until May 17 did a fair number of flycatchers, thrushes, vireos and warblers begin to pass through the region.

Records of interest include the huge flocks of Lapland Longspurs, the more than 19,465 individuals representing over half of the total birds counted. The 68 Snow Geese at Brightwater Reservoir were the first recorded since May-day counts began in 1957. All of the hawks seem to have maintained their numbers during the past four years. Short-eared and Long-eared Owls remain scarce after the peak 
rumbers of 1969. Sharp increases in two shorebirds were recorded (1970 figures given in brackets): Golden Plover 467 (18) and Dowitcher 337 (40). The following species were down in numbers: Upland Plover 3 (161), Northern Phalarope $133 \quad(3,978+)$. The 5 Bonaparte's Gulls were the first recorded on a count since 1963, as was the single Mockingbird.

Birds normally expected in mid-May and not recorded at all include the Eastern Phoebe, Cliff Swallow, Purple Martin, Long-billed Marsh Wren, Hermit Thrush, Veery, Tennessee Warbler, Ovenbird, Northern Waterthrush, Redstart, Bobolink, Baltimore Oriole, Rose-breasted Grosbeak and Whitecrowned Sparrow.-Compiled and summarized by Stan Shadick and J.F. Roy.

\section{Annual May-Day Bird Count, Regina, May 15, 1971}

On May 15, 1971, 125 species of birds were recorded in the 700 -square mile Regina area which falls within a circle 30 miles in diameter with the Legislative Buildings as its centre. Comparatively speaking, the species total for 1971 is low, probably owing to poor weather conditions slowing down the normal migration. It was particularly noticeable that there were few species of warblers (seven species only) and very small numbers of both Swainson's and Gray-cheeked Thrushes, with neither the Hermit nor the Veery being reported. On the other hand Cedar Waxwings were present (11 recorded) at an unusually early date, these being accounted for possibly by the fact that some Cedar Waxwings appeared to have wintered in the area. Most of the waders expected in midMay were present, with a record of seven Knots being of special interest for the area.

One of the serious difficulties faced by the Regina count in recent years is the scarcity of experienced observers. This factor and the fact that migrant birds are moving through the area at that time, make it impossible to obtain a complete and accurate spring count, and it must be accepted that we are dealing with approximate rather than definite numbers. Nevertheless, a general picture of the spring bird life of the area in any given season, particularly in comparison with other areas and other seasons, is possible.-Compiled by Evelyn Weisbrot and Joyce Deutscher, and summarized by Margaret Belcher.

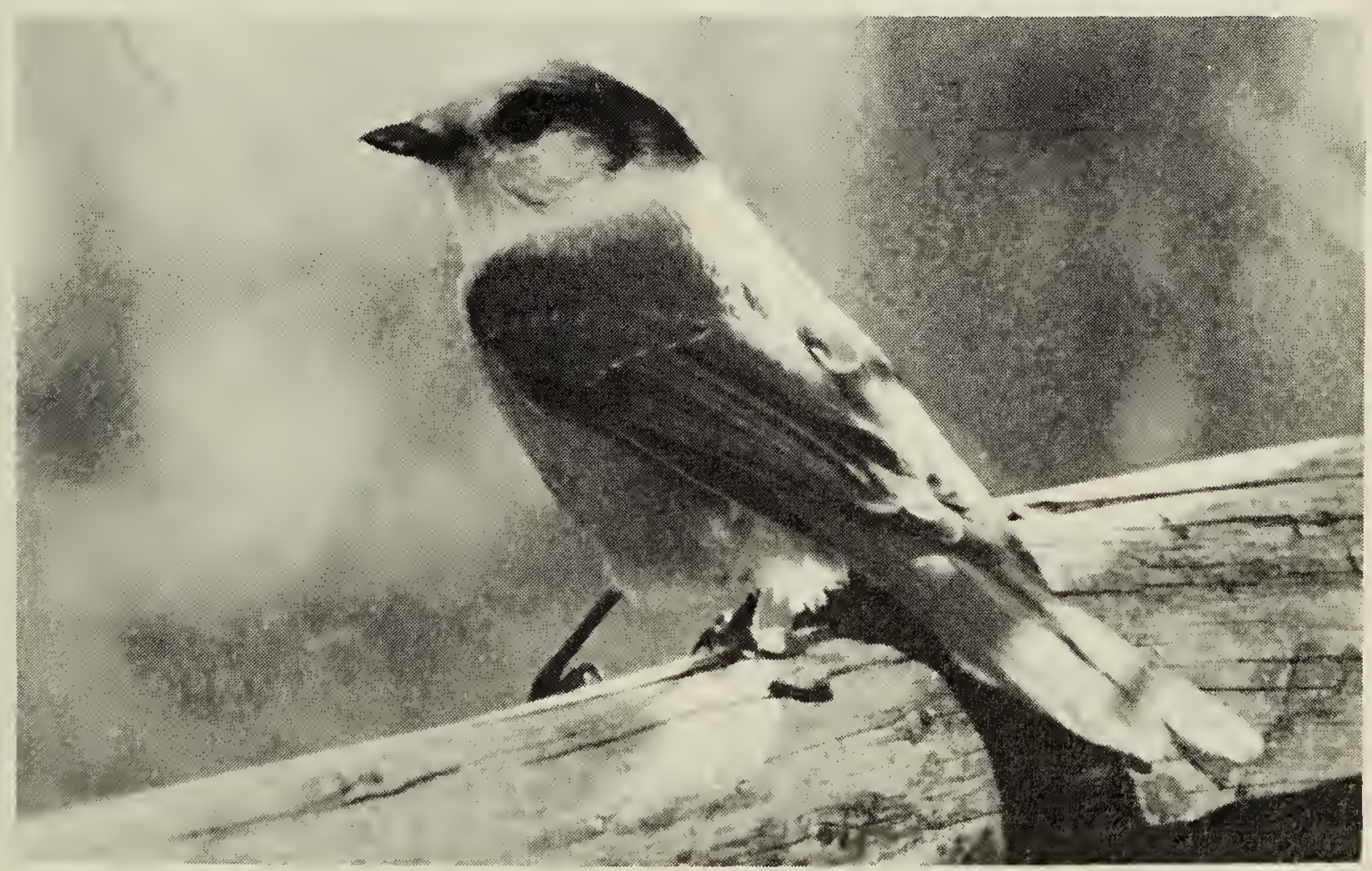

Gray Jay

Photo by R. A. Mitchell, The Pas 